\title{
Emilio Rosario Pacahuala \\ Clío en cuestión. Trabajos sobre historia e historiografía
}

\section{Lima, Fondo Editorial de la UNMSM y SHRA, 2012}

\author{
Javier Saravia
}

Emilio Rosario, director del Seminario de Historia Rural Andina (SHRA), nos presenta una compilación de artículos dedicados a la reflexión historiográfica. Los artículos que conforman el libro aparecieron originalmente en revistas especializadas de 2005 a 2010, y son, según palabras del autor, «balances» que permiten aproximarnos a la producción más reciente en temas puntuales, como son: 1) La historiografía contemporánea, 2) El Perú y el siglo XIX, 3) La Guerra del Pacífico y 4) Manuel González Prada.

La primera parte, «Por los sinuosos devenires de Clío: La historiografía contemporánea», hace un recorrido por el legado metodológico de la historiografía occidental, desde el frío y acrítico análisis positivista, pasando por las propuestas originales del marxismo y la escuela de los Annales, hasta el estancamiento de dichas corrientes y el posterior desencanto del posmodernismo. Caracteriza el periodo posterior al posmodernismo como uno de escepticismo y de una «balcanización» de los esfuerzos por recuperar «las ideas sobre el devenir de la ciencia histórica» (p. 6). Su preocupación fundamental, no obstante, se concentra en una crítica a la historiografía nacional, a la que considera poco creativa aludiendo, en primer lugar, según el autor, al «desinterés de los historiadores en buscar los orígenes, las constantes mutaciones y puntos de quiebre de su propia disciplina» (p. 10) y, segundo, a «la ausencia de una verdadera tradición académica» que incentive a realizar investigaciones de carácter epistemológico dentro de la disciplina (p. 10).

En «El Perú y el S. XIX: Un balance bibliográfico (1996-2002)», se rescatan los aportes de diferentes investigadores en el conocimiento de temas obviados por la historiografía precedente, como fueron los casos de los grupos periféricos o marginados (mujeres, minorías étnicas, clases populares) y que con el pasar de los años se convertirán en verdaderos actores políticos. No obstante ello, para el autor existe un exaltamiento injustificado de la «visión liberal de la historia», puesto que la presencia de una 
apariencia formal de «ciudadanía» y la adopción del sistema democrático no reflejaban la realidad de una sociedad como la peruana, que tenía como mecanismo fundamental y funcional un racismo estructural que impedía el respeto pleno de los ideales liberales acogidos. Sigue siendo válida la tesis del jurista Fernando de Trazegnies de definir a la entrada del capitalismo en nuestro país como «modernización tradicionalista» ${ }^{1}$ : la adopción del modelo capitalista no significó la extinción del sistema precedente heredado del virreinato y, muy por el contrario, lo dinamizó y dio fundamentos modernos para mantener la desigualdad.

En opinión de quien escribe estas líneas, el Perú tiene tres momentos fundantes de su nacionalidad. El primero de ellos fue la conquista del imperio del Tahuantinsuyo, cuando se asume una explicación (errada o no) de las razones del atraso económico del país; el segundo fue la Guerra del Pacífico, una situación sin precedentes cuyas secuelas Ilegan hasta la actualidad a través del profundo resentimiento entre las naciones involucradas; y, finalmente, más recientemente, el proceso de guerra interna de las décadas de 1980 y 1990, que nos dividió como país y cuyas secuelas, tras la Comisión de la Verdad y Reconciliación, aún estamos en proceso de asimilar.

En años recientes, la Guerra del Pacífico ha sido objeto de un renovado interés por parte de los historiadores, que intentan entender este periodo de nuestra historia desde una perspectiva diferente e integral. Para comprender mejor los derroteros actuales de la investigación, Emilio Rosario en « $(\mathrm{Re})$ construyendo la derrota. La Guerra del Pacífico y sus escritos (1884-2010)» hace una periodificación de la historiografía sobre el tema en: 1) «Una revisión de la crónica de los vencidos (1884-1910)», 2) «Remembranzas a los hijos de la guerra (1910-1950)», 3) «Nuevos enfoques, vieja esencia (1950-1979)»,4) «Celebrando la centuria (1979)», 5) «Recreando nuevos discursos (1979-2004)»y, en último lugar, 6) «El discurso del otro, ahora es nuestro (2004-2010)». No se muestra muy optimista sobre los logros alcanzados en la investigación sobre el periodo, a la cual califica de rendir un excesivo culto a las fechas conmemorativas (p. 107). No obstante ello, se reconoce el mérito de haberse encontrado nuevas vetas para la investigación y el nutrirse de nuevas fuentes documentales para enriquecer el debate.

Finalmente, en «Horas de escritos. Una aproximación bibliográfica a la vida de Manuel González Prada (1844-1918)», hace una reconstrucción de la vida del ilustre escritor, partiendo de la bibliografía disponible tras

1 Trazegnies, Fernando de (1979). La idea de derecho en el Perú republicano del siglo XIX. Lima: Fondo Editorial de la Pontificia Universidad Católica del Perú, p. 30 
la muerte de Prada, uno recopilación de libros, artículos, ensayos y tesis publicadas durante 90 años, en los que se exploran los diversos momentos de la vida de don Manuel. Siempre a contracorriente, Rosario propone una crítica obvia pero obviada por la mayoría de escritores que elogian al anárquico intelectual. Sobre él nos dice: «Pero lejos de constituirlo como un rebelde, es claro denotar que hubo intereses personales de por medio para convertirse en un hombre público/político» (p. 131).

Los ensayos tienen contenidos muy heterogéneos, pero en conjunto son un importante esfuerzo por reflexionar sobre la producción historiográfica local y el quehacer de los historiadores, tema sobre el cual no se está escribiendo con la frecuencia que se debería ni reflexionando aún lo suficiente. Una obra sugerente para una puesta al día de los derroteros de la historiografía nacional. 